\title{
Issues of land reform and Poland's post-war borders in the broadcasts of Tadeusz Kościuszko Radio Station
}

Outline of contents: Between 1941 and 1942, one general radio station, and 16 secret foreign-language (national) stations operated from Soviet territory; among them was the Polish-language Tadeusz Kościuszko Radio Station, which began operations in August 1941, and functioned until 22 August 1944. According to the broadcasters, the land reform should consist in expropriating the owners of large landholdings, and distributing their possessions among peasants and farm labourers. As regards the Poland's future borders, the broadcasters presented the position of their political superiors, according to whom the eastern voivodeships of the Polish Republic should be transferred to the Ukrainian, Belarusian and Lithuanian Soviet Republics.

Keywords: Tadeusz Kościuszko Radio Station, Communist International (Comintern), Polish communists, Polish post-war borders, land reform

During its three-year existence, the Tadeusz Kościuszko Radio Station addressed many subjects relevant to Polish citizens who found themselves under German occupation. Among the key issues discussed, two merit special attention: the land reform and Poland's post-war borders.

The main idea behind the planned socio-economic changes was, according to the Polish left, the need to cut ties with a bygone reality, strange to the "simple" man (peasants and workers). This can be concluded from the station's broadcasts. Their authors claimed that the relations of property prevailing in the Polish countryside in the interwar period were incompatible with the needs of the peasants.

One extremely important issue addressed in the broadcasts was that of Poland's post-war borders. The arguments expressed therein with regard to the future shape of the Polish-Soviet border deserve some focus. At a meeting of the National Council on 24 February 1942, Prime Minister Władysław Sikorski proclaimed the Declaration of the Programme of the Polish government, which set out the principles 
that were to serve as a foundation for the restoration of the Polish Republic. According to the Declaration, "the future political and economic system of the Polish state will be decided by the Sejm of independent Poland", while the objective of a rational land reform will be the creation of small agricultural holdings, essentially administered by the family of the owner, yet independent, cost-effective, and with decent "production capacity". The Declaration, however, would not specify any details concerning the principles of the parcellation process (maximum allotment, amount of compensation for lost property etc.).

The formal position of Stanisław Grabski - Chairman of the National Council, prominent politician and economist - in respect of the agrarian transformations in reborn Poland was typical of the governing circles. As the reserve of land that could be divided into smaller holdings was scarce in Poland, he put forward the idea of amending the pre-war land reform act. The revised law would leave $8 \%$ of arable in the hands of former landholders. Dwarf farms would be expanded to 4-6 ha on average, and to 5-10 ha in mountainous regions and in the western voivodeships. Folwark estates, according to Grabski, would have a size of 100-160 ha. ${ }^{1}$

On 15 March 1944, the Praesidium of the Council of National Unity ${ }^{2}$ (RJN) approved the declaration What does the Polish nation fight for?, constituting the programme of the socio-economic reconstruction of Poland. It included a passage detailing the land reform that ought to be carried out once the Second World War ends: the Polish state would take over private holdings exceeding 50 ha. The farms would be $8-15$ ha in size, and the forests would be nationalised. Those among the rural population, who would fail to find employment in agriculture, would be reoriented to work in industry, commerce and communication. ${ }^{3}$

This declaration of the RJN came as a response to the programmes of the communist left developed in 1943-44 in occupied Poland.

\footnotetext{
1 W. Góra, PPR w walce o podziat ziemi obszarniczej 1944-1945, Warszawa, 1962, pp. 52-53. For information on the land reform of the Polish Government during the Second World War, see: H. Słabek, O społecznej historii Polski 1945-1989, Warszawa, 2009, pp. 41-46.

2 The Council of National Unity (Rada Jedności Narodowej, RJN) was formed on 8-9 January 1944 as a result of the transformation of the National Political Representation, by decree of the Government Delegate dated 9 January 1944. This decision came as a response to the establishment of the State National Council by the Polish Workers' Party (Polska Partia Robotnicza, PPR). The Council of National Unity was an organisation associated with the London cabinet, acting as the political division of the Polish Underground State. It operated in the years 1944-1945. The position of Chairman of the Council of National Unity was given to Kazimierz Pużak of the Polish Socialist Party - Freedom, Equality, Independence (PPS-WRN).

3 Programy polskich partii politycznych i ugrupowań partyjnych lat wojny i okupacji hitlerowskiej, ed. K. Przybysz, Warszawa, 1987, p. 166.
} 


\section{The activity of Polish communists in occupied Poland in 1939-1941 and the establishment of the Polish Workers' Party}

The German-Soviet alliance that was in force between 1939 and 1941 prevented the Polish communists (who found themselves in Soviet-controlled territory in 1939) from rebuilding their party, as the Executive Committee of the Communist International refused to give its consent. The communists in occupied Poland had their hands tied as well.

Following the dissolution of the Communist Party of Poland on 16 August 1938 by the Praesidium of the Executive Committee of the Communist International, the Polish communist milieu suffered complete disintegration, which naturally resulted from both their dependence from the Moscow circles, and their scant influence on the Polish society.

In the General Government, which covered a part of the occupied Polish Republic, the activity of former activists of the Communist Party of Poland (KPP) consisted essentially in keeping in with former colleagues and listening to Soviet radio. Only a few of them created small groups that would conduct modest propaganda and self-educational activities. Among such groups was the Central Committee of Polish Workers' and Peasants' Soviets, also known under the name of the organisation's official periodical, Młot $i$ Sierp (Hammer and Sickle). ${ }^{4}$ This group associated the ongoing conflict to the war of 1914-1918, describing it as a "conspiracy of international capital" aimed at the well-being of the working class.

Even though it disposed of some of the "technology" of the former KPP, the Młot $i$ Sierp group operated in isolation. The fact that it acted in defiance of Moscow's prohibition was reason enough for the communist milieus to perceive their activity as a provocation. The revolutionary stance of Młot i Sierp was shared by the members of the Peasant-Worker Deed. This organisation was active in the Rzeszów area and consisted mostly of radical-communist peasant activists. They argued that the fall of the Third Reich was a prerequisite for the triumph of the revolution; therefore, they believed that the efforts of the Anglo-French bourgeoisie in bringing an end to Nazi Germany should be supported.

Communist slogans and traditions were also an inspiration for the "Spartacus". This rather small group, consisting primarily of Warsaw's Jewish youth, followed the programme of worldwide proletarian revolution. They did not even aspire to put forward any independent thought that could be considered a programme.

\footnotetext{
${ }^{4}$ The literature also quotes the name Revolutionary Workers and Peasants' Soviets (but it is the same organisation).

5 The term "technology" most often refers to the equipment used to print illegal publications, or to the structure of the communist conspiracy involved in that activity.
} 
Another organisation that existed in the General Government before the outbreak of the German-Soviet war was the Association of Friends of the Soviet Union, led by Antonina Sokolicz and August Bukowiecki. ${ }^{6}$

Following Germany's invasion of Poland on 1 September 1939, a number of Polish communists from the former KPP evacuated to the easternmost voivodeships of the Second Republic, which soon have been occupied by the Red Army. In the early period of the war, i.e. before the Third Reich attacked the Soviet Union on 22 June 1941, the Polish left was concentrated mainly in three larger cities: Lwów, Białystok and Wilno, and later also in Minsk. In Lwów, the communists gathered around the editorial staff of the Polish-language periodicals Czerwony Sztandar ${ }^{7}$ and Nowe Widnokregi. The latter began to appear in March 1941 as a Soviet socio-cultural monthly for Poles living in the USSR. Seven issues overall were published in 1941.

Several writers, journalists and political activists devoted their time to these periodicals as members of editorial teams or co-operators. The list of contributors of Nowe Widnokregi included: Wanda Wasilewska, Helena Usijewicz, Tadeusz Boy-Żeleński, Władysław Broniewski, Jerzy Putrament, Adam Ważyk, Stefan Jędrychowski, Janina Broniewska, Zofia Dzierżyńska. Playwright Oleksandr Korniychuk, too, cooperated with the Poles on behalf of Central Committee of the Communist Party of Ukraine (Bolsheviks). ${ }^{8}$ Władysław Gomułka, future general secretary of Central Committee of the PPR, was also present in Lwów at that time.

In Białystok - the base of operations for former members of the KPP and of the Polish Communist Youth Union (KZMP) - were active Marceli Nowotko, Alfred Lampe, Paweł Finder, and Jan Turlejski. ${ }^{9}$ The Minsk-based newspaper Sztandar Wolności co-operated inter alia with Stefan Wierbłowski, Józef Kowalski, Czesław Skonecki, and Teofil Głowacki. ${ }^{10}$

Germany's invasion of the Soviet Union brought a new political situation, which allowed the Comintern to undertake action in order to establish a communist party with the participation of Polish activists. On 27 August 1941, in a conversation with the Secretary General of the Comintern, Joseph Stalin outlined the rules of operation of the new communist party in Poland. After the aforementioned

${ }^{6}$ P. Gontarczyk, Polska Partia Robotnicza. Droga do władzy (1941-1944), Warszawa, 2006, pp. 55-56.

7 For more on the editorial board of Czerwony Sztandar, see: B.B. Gogol, Czerwony Sztandar. Rzecz o sowietyzacji ziem Małopolski Wschodniej, wrzesień 1939-czerwiec 1941, Gdańsk, 2000, pp. 18, 20-21; A. Cieślikowa, Prasa okupowanego Lwowa, Warszawa, 1997, p. 34; E. Czop, Obwód lwowski pod okupacją ZSRR w latach 1939-1941, Rzeszów, 2004, pp. 216-217; G. Hryciuk, Polacy we Lwowie 1939-1944. Życie codzienne, Warszawa, 2000, p. 102.

${ }^{8}$ K. Sobczak, “Z genezy Armii Polskiej w ZSRR”, Wojskowy Przegląd Historyczny, 3 (1973), pp. 122-123.

9 Id., "Geneza Związku Patriotów Polskich w ZSRR i 1 Dywizji Piechoty im. Tadeusza Kościuszki. Maj 1942-czerwiec 1943 r.”, Wojskowy Przegląd Historyczny, 1 (1963), p. 5.

${ }^{10}$ Id., Z genezy Armii Polskiej, p. 123. 
meeting, Dimitrov noted in his diary the dictator's instructions: "It would be better to establish a Polish Workers' Party with a communist programme. A communist party could deter not only strangers, but even some of our sympathisers. At the current stage," as Stalin put it, "the struggle for national liberation is of utmost importance. However, it is obvious that this will not be a typical labour party". ${ }^{11}$

In late 1940, several activists, including Marceli Nowotko and Lucjan Partyński, were summoned to Moscow and sent to Comintern academy, ${ }^{12}$ originally located in Nagornoye, then moved to Pushkin near Moscow. ${ }^{13}$ Thus began the training of the first "initiative group" of Polish communists, which also consisted of: Paweł Finder, Anastazy Kowalczyk, Bolesław Mołojec, Feliks Papliński, Czesław Skonecki, and Jan Turlejski. They were the first among the Polish communists to hear from Georgi Dimitrov, in late July 1941, that the leadership of the International expressed support for their initiative to rebuild the revolutionary party in Poland, and that they would receive assistance in reaching the occupied country in order to undertake their duty. Dimitrov also stated that the aforementioned activists would form the Initiative Group ${ }^{14}$ of the future party. At the next meeting (September 1941), Dimitrov proposed selecting several members who, upon arrival in the country, would form the party's temporary leadership. Paweł Finder, Bolesław Mołojec, and Marceli Nowotko were chosen for this mission.

The members of the Initiative Group pursued discussions on the program of the future party on 1 and 6 September 1941; their meetings, which took place at the Communist International's academy in Pushkin, were classified. It was decided that the newly-formed party would not be formally associated with the Comintern. ${ }^{15}$

After deliberations, Nowotko's draft version of the ideological statement was adopted, ultimately in the form of a proclamation entitled To the workers, peasants

11 Gontarczyk, Polska Partia Robotnicza, p. 73.

12 A. Sobór-Świderska, Jakub Berman. Biografia komunisty, Warszawa, 2009, p. 58. The Comintern operated several establishments, including those in Nagornoye and Pushkin, where Polish communists were trained. One more was known to exist, probably in Skhodnya. Following the evacuation of the Communist International from Moscow in September/October 1941, the training centre was transferred to Kushnarenkovo near Ufa. For more on this subject, see: Gontarczyk, Polska Partia Robotnicza, pp. 80-81.

13 Góra, PPR w walce, pp. 58-59. See also: N. Kołomejczyk, Paweł Finder, Warszawa, 1977, p. 97.

14 There was also a second group trained in case the first one had failed; it was composed of: Aleksander Kowalski, Małgorzata Fornalska, Jadwiga Golszlak-Ludwińska, Piotr Drążkiewicz, Jan Krasicki, Jan Gruszczyński, and two radio operators: Mieczysław Hejman and Wacław Stec.

15 The PPR Initiative Group is mentioned in: M. Szumiło, Roman Zambrowski 1909-1977. Studium $z$ dziejów elity komunistycznej w Polsce, Warszawa, 2014, p. 136. For more on the situation of Polish communists in the USSR during the Second World War, see: M. Szumiło, "Kierownictwo Polskiej Partii Robotniczej (1944-1948) - portret historyczno-socjologiczny”, Kwartalnik Historyczny, 2 (2014), pp. 305-306; id., "Kadra kierownicza centralnego aparatu PPR w latach 19441948”, Res Historica, 34 (2012), p. 114; id., “I sekretarze Komitetów Wojewódzkich PPR (19441948 ) - portret zbiorowy”, Dzieje Najnowsze, 4 (2013), pp. 50-51. 
and intelligentsia! To all Polish patriots. Its contents expressed both ideas reflecting the experiences and considerations of the Polish communists who endured a long and painful journey, and the new political line of the Comintern.

The further conduct of their activities was defined by the guiding principle of the Communist International, aimed at creating a broad national front, combining all political forces in Poland willing to oppose the Nazi occupants. Particular emphasis was placed on tasks related to national liberation, without losing sight, however, of the already pressing social and political issues that would need to be resolved in future, democratic Poland, yet without putting forward revolutionary slogans. Dimitrov presented the contents of the proclamation to Stalin on 16 September $1941 .^{16}$

The declaration of the programme of the Polish Workers' Party from January 1942 included the statement that all agricultural land would belong to the Polish peasants. $^{17}$

\section{The land reform}

The issue of the land reform appeared in the broadcasts of the Tadeusz Kościuszko Radio Station only in 1943. At that time, the Polish Workers' Party, which had been operating in occupied Poland since January 1942, had already issued its programme declarations. The first proclamation, dated 1 March 1943, was entitled What are we fighting for? ${ }^{18}$ With regard to agrarian reforms, the document announced the restoration of land to the peasants expropriated and displaced by the occupant. The owners of large landholdings exceeding 50 ha would see their land confiscated without compensation. The declaration stated that this land would be given out to smallholder peasants and farm labourers. ${ }^{19}$ There is no mention of the fate of medium-size farms.

16 R. Nazarewicz, Komintern a lewica polska. Wybrane problemy, Warszawa, 2008, pp. 128-129.

17 Kształtowanie się podstaw programowych Polskiej Partii Robotniczej w latach 1942-1945. Wybór materiałów i dokumentów, Warszawa, 1958, p. 14; A. Przygoński, Z zagadnień strategii frontu narodowego PPR 1942-1945, Warszawa, 1976, p. 45; Polska Partia Robotnicza. Dokumenty programowe 1942-1948, Warszawa, 1984, p. 54.

18 The leadership of the PPR formulated this declaration in the conviction that, in view of the recent successes of the Soviet troops inspired by the failure of the German army at Stalingrad (2 February 1943), Poland would soon be liberated. After one year of activity, it was also deemed necessary to formulate the party's stance on other official and conspiratorial parties, as well as the government-in-exile, considering that talks with the latter's Government Delegation for Poland and the Home Army were already under way. The declaration contained the programme objectives for the PPR and its members.

19 Kształtowanie się podstaw programowych, pp. 94-95; Polska Partia Robotnicza. Dokumenty, p. 122; Dokumenty programowe polskiego ruchu robotniczego 1878-1984, eds. N. Kołomejczyk, B. Syzdek, Warszawa, 1986, p. 281; M. Nadolski, Kwestia chłopska w polityce stronnictw robotniczych i ludowych $w$ Polsce w latach 1941-1947, Warszawa, 1990, p. 9. 
The party's subsequent declaration from November 1943, entitled What are we fighting for?, was a response to Dimitrov's criticisms addressed on 2 April 1943 to the leadership of the party. The Secretary General of the Comintern reacted with disapproval to the first proclamation, as he found its tone imprecise and sectarian..$^{20}$ The Central Committee of the PPR decided to formulate a new programme declaration, as their talks with the Government Delegation for Poland and the Headquarters of the Home Army in February 1943, in hopes of engaging in common action against the occupying forces, had ended in failure. The victories of the Red Army in 1943 were also of significance for the Polish communists operating in conspiracy in occupied Poland.

The aforementioned programme declaration stated that "the reins of power in future Poland must be handed to the representatives of the broadest classes in the nation, who represent the interests of the workers, the peasants and the intelligentsia". Consequently, chapter III point 9 of the declaration states that the post-war "Provisional Government shall confiscate all large landholdings and mortmain property without compensation, and divide this land between peasants and farm labourers in consultation with their representatives". The declaration also upholds all cases of expropriation of land carried out by peasants and farm labourers during the expulsion of the occupant". ${ }^{21}$

The November declaration also entitled the owners of medium-size farms to benefit from the land reform. The document from November 1943, unlike the March declaration, did not specify the upper size limit for farms not subject to parcellation. On the other hand, it requested the recovery of small and medium-size farms to their owners, who had been "robbed and deported by Germans". ${ }^{2}$

The demand for a land reform was included in the Declaration of the Ideology of the Union of Polish Patriots (ZPP) in June 1943. The document assumed that the peasants (the landless, smallholders, and farm labourers in the first place) would receive the land free of charge. Much attention was devoted to this issue in 1943 in the official press of the Union of Polish Patriots.

As regards the planned land reform to be carried out after the end of the war, the ZPP prepared a draft programme of changes of ownership in the Polish countryside. The final result was the land reform project prepared in April 1944 by the Bureau of Economic Research of the General Board of the ZPP.23 The plan

20 Gontarczyk, Polska Partia Robotnicza, p. 221.

${ }^{21}$ Ksztaltowanie sie podstaw, p. 147; Polska Partia Robotnicza. Dokumenty, p. 154; Dokumenty programowe, p. 300. For more on the postulates concerning the land reform contained in the PPR Declaration from November 1943, see also: M. Nadolski, Komuniści wobec chłopów w Polsce 1941-1956: mity i rzeczywistość, Warszawa, 1993, p. 101.

22 Góra, PPR w walce, pp. 63-65.

23 The Bureau of Economic Research was established by the Praesidium of the General Board of the Union of Polish Patriots at a meeting on 10 March 1944. It was headed by Hilary Minc and consisted of: M. Popiel, Władysław Kuczewski, Henryk Różański, Roman Werfel and Leon 
assumed the establishment of the State Land Fund, which would cover all possessions previously owned by Germans or their collaborators, as well as ownerless land and estates of over 100 ha. The parcellation would benefit the smallholders, owners of medium-size farms with large families, and farm labourers. A certain portion of land would be reserved for people resettled from areas deficient in arable soil, and for model farms. As regards the territories recovered from Germany, a different Land Fund based on separate regulations was to be established. The land would be parcellated and given to repatriates, or owned by the state.

The project of the Bureau of Economic Research, unlike the PPR, advocated the confiscation of large landholdings with some compensation. Their form and size should be determined by the Legislative Sejm, with regard to the owners' merits in the fight against the occupier. The State Land Fund was responsible for the allocation of land for a fee not exceeding $20 \%$ of its pre-war price, or of the annual gross income from the newly-acquired land. ${ }^{24}$

The Tadeusz Kościuszko Radio Station first addressed the subject of land reform in its broadcast of 12 April 1943. Another broadcast of August 11 suggested that the expropriated people would not receive compensation for their property, but this would only apply to landed gentry. "Large landholdings should be confiscated, and the properties of landed gentry should be distributed among peasants and farm workers without compensation. Of course, the expropriation cannot in any case [emphasis mine - A.K.] apply to land owned by peasants, regardless of the size of their holdings". 25

The planned land reform was to benefit the landless peasants and farm labourers in the first place. Consequently, this demand coincided with the later assumptions of the project developed by the Bureau of Economic Research of the ZPP. This is proof that these social groups were to be covered by the land reform from the very beginning. It should be noted that the broadcast was transmitted one year prior to the reform project developed by the Bureau of Economic Research.

The broadcast of 4 January 1944 was marked by a shift in the attitude towards the issue of compensation for confiscated land. It was now deemed necessary, especially with regard to those who had fought during the occupation for the independence Poland and paid the highest price. "Of course, the families of those landlords, who have participated in the struggle for independence, or even have sacrificed their lives for their Motherland, should receive decent compensation". ${ }^{26}$

Urzędowski. The land reform project was developed in great haste by M. Popiel and R. Werfel under the direction of $\mathrm{H}$. Minc.

${ }^{24}$ C. Madajczyk, Sprawa reformy rolnej $w$ Polsce 1939-1944. Programy i taktyka, Warszawa, 1961, pp. 178-179; Z. Kumoś, Związek Patriotów Polskich. Założenia programowo-ideowe, Warszawa, 1983, pp. $169-171$.

25 Broadcast of 11 August 1943, Archives of Modern Records in Warsaw (hereinafter: AAN), Radiostacja "Kościuszko", no. 321, vol. 17, fol. 171.

${ }^{26}$ Broadcast of 4 January 1944, ibid., vol. 22, fol. 47. 
One of the conditions taken into account was that peasants owning arable land (called "medium-size farmers") should not receive additional allocations. The broadcast of 4 January 1944 stated as follows: "The more affluent peasants, those owning 20-30 hectares of land or more, do not require additional land to operate their agricultural holding efficiently and beneficially for both the state and themselves; they are fine with what they already have" ${ }^{27}$

Before the plan of revising the ownership structure in the Polish countryside was prepared in April 1944, the Tadeusz Kościuszko Radio Station put forward the idea of creating an institution that would own and manage the reallocated land. The land obtained from expropriated Polish landed gentry and German owners would be handed over to the Polish peasants. The broadcast of January 4 stated that "the National Land Fund managing the possessions subject to parcellation will undoubtedly benefit from the expropriation of the Germans, which will provide new opportunities for hundreds of thousands of peasant families, especially in the western lands".

The same broadcast addressed the issue of providing support to the peasantry in the light of the destruction caused by the German occupier. "We will have to introduce loans for peasants, help them settle, and assist them in the management of live and dead stock" ${ }^{28}$

According to the political leadership of the radio station, the main goal of the land reform in the Republic of Poland was to "break with the past". The Polish communists believed that handing the land over to the Polish peasants would contribute to the modernisation of the country's economy, and that the peasants and the working class would become the foundation and true strength of the state. The broadcast of 12 April 1943 stated as follows: "Once free from Nazi slavery, Poland cannot return to being a country where the peasants are starving due to lack of land, it cannot be a semi-feudal country of latifundia and landed estates. The Polish peasants are the mainstay of the Polishness of our lands. The economic, cultural and military progress of the Polish state will rely on the labour of our workers and peasants, on the creativity of our intelligentsia, on the collective work of all productive elements of our nation". ${ }^{29}$

The same broadcast pointed out that post-war Poland could no longer accommodate the landed gentry that contributed to the backwardness of the country and its fall in the $18^{\text {th }}$ and $19^{\text {th }}$ century: "For centuries, the magnates and aristocrats have been the backbone of reaction and backwardness, bearers of immorality and greed, the source of weakness of our Motherland. Twice have they brought Poland to ruin". ${ }^{30}$

\footnotetext{
27 Ibid.

28 Ibid.

29 Broadcast of 12 April 1943, ibid., vol. 14, fol. 170.

${ }^{30}$ Ibid.
} 
The land allocation ensured by the land reform was to constitute a compensation for the losses suffered by the peasants during the war and the occupation (mass executions carried out by the Germans), but also to ensure the improvement of the material condition of the Polish countryside, poverty-stricken even back at the times of the Second Republic. This was made apparent by the broadcast of 28 August 1943: "It is clear that this four-year torment and the rivers of blood shed by the peasantry cannot go to waste. Our peasants hope that the years of martyrdom and the fire of the great liberation war will finally bring us a Poland that will be like a mother to us, rather than a stepmother...". ${ }^{31}$

Rural self-government was to provide the peasantry with progress and prosperity, all while guaranteeing civil liberties, which would later become the overriding values of the Polish countryside in post-war reality. The broadcast of 14 April 1944 stated: "By enforcing significant self-government, we will guarantee our peasantry an independent, truly democratic Poland marching on a path of rapid economic, social and cultural progress". ${ }^{32}$

The same broadcast pointed out that, in the future, the peasantry would be supported by new authorities that would contribute to economic development: "State aid and long-term loans will give peasants the opportunity to fully benefit from modern advances in science and from the benefits of mechanisation. The Polish peasant will thus carry the agrarian culture, improve soil fertility, multiply the population of cattle and poultry, increase the production of cash crops and preparations". ${ }^{33}$

In summary, the position of the Tadeusz Kościuszko Radio Station on land reform was that land owned by large holders should be parcellated and handed over to peasants and farm labourers. What is worth pointing out is that land was only to be given to farmers who had conducted pro-independence activities during the Second World War. Another demand of the broadcasters stipulated the recovery of farms to those peasants, who lost their possessions on account of the occupier's legislation. One inherent element of the land reform was to provide the peasants with broadly defined financial support. The plans included the creation of rural councils that would guarantee the proper development of the countryside.

The radio station would address the issue of land reform on the grounds that this topic was already being discussed by the Polish Communists from the ZPP and PPR. It was crucial in the light of the land hunger, which affected the peasants during the interwar period. Undoubtedly, the interest of the communists in this matter stemmed from the desire to win the favour of this part of the population. The Polish left would eventually develop several concepts of the change of ownership in the Polish countryside, as it was difficult to establish a single variant that would be implemented in post-war conditions. When assessing the achievements of the

\footnotetext{
${ }^{31}$ Broadcast of 28 August 1943, ibid., vol. 17, fol. 402.

32 Broadcast of 14 April 1944, ibid., vol. 25, fol. 188.

33 Ibid., fol. 189.
} 
Polish radio station, it must be noted that, despite its importance, the topic of land reform was not predominant in its broadcasts.

\section{Post-war borders of Poland and ethnic issues in the Eastern Borderlands}

In the opinion of Polish communists, the success of the land reform would be possible by the incorporation of the so-called Western Lands.

In the spring and summer of 1943, the press of the Union of Polish Patriots increasingly paid more attention to the future Polish-German frontier, as they promoted the idea of pushing the border toward the Oder and the Baltic, the execution of which was perceived as one of the foundations of Poland's freedom and independence. The Polish communists in the Soviet Union took sudden interest in this subject in view of Germany's defeat at Stalingrad, and Moscow's formal position on the post-war delimitation between the USSR and Poland announced on March 1, as will be discussed below. Undoubtedly, their interest could also were affected by the breakup of diplomatic relations with the Polish government by the Soviets on 25 April 1943.

The preliminary reflections on the territorial shape of Poland were summarized in the programme article of Alfred Lampe, chief ideologist of the Union of Polish Patriots, entitled "The Place of Poland in Europe" (published on 16 April 1943 in Wolna Polska). Lampe emphasised that Poland's safety in post-war Europe could be guaranteed by depriving Germany of all bases of operations in Silesia and at the Baltic Sea. Therefore, these territories should be incorporated into Poland. According to him, the Polish-German border had to run along the "Oder line" in order to protect Europe from another aggression on the part of Germany. ${ }^{34}$

The demand concerning Poland's post-war borders was included in the Declaration of the Ideology of the Union of Polish Patriots passed by the Congress of the ZPP (9-10 June 1943) and published on 16 June 1943 in Wolna Polska. This document rejected the borders laid down by the Treaty of Riga as incompatible with the aspirations of Ukrainians and Belarussians to their own national reunification. In reference to the tradition of "the great builders of the Polish state, i.e. Boleslaus I the Brave, Boleslaus III Wrymouth, and Ladislaus I the Elbow-high", it reflected the wish to strengthen Poland in the west and at the Baltic Sea. The issue of the border with Czechoslovakia was left open, underlining that it should be regulated in consultation with the revived Czechoslovak state in a peaceful way, so as not to affect the lasting friendship of the two nations. ${ }^{35}$

\footnotetext{
${ }^{34}$ M. Orzechowski, Odra - Nysa Łużycka - Bałtyk w polskiej myśli politycznej okresu drugiej wojny światowej, Wrocław-Warszawa-Kraków, 1969, pp. 133-135.

35 Deklaracja ideowa Związku Patriotów Polskich, ed. E. Syzdek, Lublin, 1983, pp. 53-54; Kształtowanie sie podstaw, pp. 454-455. For more on the formal position of the ZPP on the future
} 
Another proof of the efforts of Polish left in the USSR in developing a concept for the post-war borders of the Polish Republic was the document defined in the literature as Thesis no. 1. It was created in October 1943 by Jakub Prawin, educational and political officer at the $1^{\text {st }}$ Corps of the Polish Armed Forces in the USSR. This document contained the demand that "the historical Polish lands up to the Oder and the Baltic Sea be incorporated into Poland, and the German population expelled to Germany". ${ }^{36}$ The settlement of the issue of Poland's eastern border was to be reached with respect for the will of the Ukrainian, Belarusian and Polish nations, and in consultation with the befriended Soviet Union. ${ }^{37}$

It should be added that the question of the future Polish-Soviet border had been settled back in the autumn of 1939, when the Soviet government carried out the so-called elections to the People's Assemblies in the territories of the easternmost voivodeships of the Polish Republic occupied by the Red Army. They took place in an atmosphere of terror on 22 October 1939 in "Western Ukraine" and "Western Belarus". These assemblies then issued requests (27 and 29 October 1939 respectively) to the Supreme Soviet of the USSR asking for the incorporation of these areas into the already existing Ukrainian and Belarusian Soviet Republics. The Supreme Soviet responded by approving these requests (1 and 2 November 1939 respectively), and four weeks later (November 29) the Praesidium of the Supreme Soviet issued a decree confirming the acquisition of citizenship by the residents of Western Ukraine and Western Belarus. ${ }^{38}$

Soviet diplomacy sought to obtain recognition of these decisions, i.e. the annexation of Poland's eastern voivodeships to the USSR, by its coalition partners (the United States and Great Britain) throughout the Second World War. This also applied to: the Baltic States, absorbed by the Soviet Union in 1940; Karelia and the Petsamo area (now Pechenga), lost by Finland in the Winter War of 1939-40; and Northern Bukovina and Bessarabia, annexed by the USSR in 1940, then occupied by Romania in 1941 (returned to the USSR after the war).

borders of Poland, see: E. Prus, "Problem ziem zachodnich w działalności Związku Patriotów Polskich w ZSRR”, Zaranie Śląskie, 3 (1974), pp. 462-481.

36 Organizacja i działania bojowe Ludowego Wojska Polskiego w latach 1943-1945, vol. 4: Działalność aparatu polityczno-wychowawczego, ed. I. Blum, Warszawa, 1963, p. 100. Another document was developed in October 1943: An outline of the draft programme of the democratic movement of Polish émigrés in the Soviet Union, by Roman Zambrowski and Hilary Minc. This text, commonly referred to as Theses no. 2, also contains the concept of establishing Poland's western borders on the Oder and the Baltic Sea. The eastern border was to be demarcated in consultation with the USSR, but this document did not specify its exact shape (ibid., pp. 111-120); for more on this subject, see: F. Zbiniewicz, Armia Polska w ZSRR. Studia nad problematyka pracy politycznej, Warszawa, 1963, pp. 161-169; id., "Polska lewica demokratyczna w Związku Radzieckim i jej rola w organizacji ludowych regularnych sił zbrojnych w ZSRR”, in: 20 lat ludowego Wojska Polskiego, Warszawa, 1967, p. 233.

37 Zbiniewicz, Armia Polska w ZSRR, p. 151.

${ }^{38}$ Historia Dyplomacji Polskiej, vol. 5, ed. W. Michowicz, Warszawa, 1999, pp. 155-156. 
It is worth mentioning that the communique of the TASS agency dated 1 March 1943 had a significant influence on the projects of the post-war Polish-Soviet border elaborated by the Polish left in the USSR. The Soviet government asserted therein that the demarcation of the border between Poland and the USSR would be based on the Curzon Line, ${ }^{39}$ i.e. on ethnic criteria. The formal position of the Soviet authorities obliged the Polish communists to promote the concept of the post-war Polish-Soviet border in line with the interests of the USSR.

It should be added that there were more documents that touched on the issue of Poland's post-war borders in that period. One of them was the Draft Programme of the Polish National Committee ${ }^{40}$ by Alfred Lampe, written at the turn of November and December 1943, which specified the shape of the Polish-German border: "The historically Polish Silesia must be reunited with the Motherland; the mouth of the Vistula, the vital artery of our country, must return into Polish hands. Our access to the sea must be extended through East Prussia and Pomerania. The German threat lurking in the north must be eliminated. The German fortresses on the Oder cannot subsist as outlets of German imperialism looming over Polish Silesia and Polish Pomerania". In essence, the quoted fragment repeated the notions and demands known from the article Poland's Place in Europe.

As regards the future Polish-Soviet border, Lampe stated that "the borders set by the Treaty of Riga were inconsistent with our national interests, as they made our eastern border fragile and contentious, thereby weakening our state, and paralysing our defence against our eternal enemy, the greedy Germans". In this respect, he asserted: "We do not desire Ukrainian or Belarusian and Lithuanian lands. We strive to unite all Polish lands within the Polish state". ${ }^{41}$ He supported the idea of an ethnic border.

An attempt to settle the issue of Poland's post-war border was made in November 1943 by the PPR in its programme declaration What are we fighting for? The document contained demands identical to those included in the Draft Programme of the Polish National Committee, namely the idea

39 Sprawa polska w czasie drugiej wojny światowej na arenie międzynarodowej. Zbiór dokumentów, Warszawa, 1965, p. 338. The Polish-Soviet relations have been precisely described by K. Kersten: "Warianty polityki polskiej: rok 1944", in: Polska 1944/1945-1989. Studia i materiały, vol. 1, ed. M. Głowiński, Warszawa, 1995, pp. 29-61.

40 The Polish National Committee was to serve as temporary representation of the nation until the creation of the Provisional Government and the convening of the Legislative Sejm. A group of Polish communists in the USSR began working on its formation at the turn of November and December 1943. This quasi-government was to consist mainly of Polish left-wing activists from the USSR, Poland, the US, Great Britain and the Middle East. The idea was abandoned when the State National Council, which possessed the appropriate competences, was established on the night of 31 December 1943 in occupied Poland.

${ }^{41}$ Ksztaltowanie się podstaw, p. 481. For more on the establishment of the State National Council, see: E. Syzdek, Działalność Wandy Wasilewskiej w latach drugiej wojny światowej, Warszawa, 1981, pp. 225-228. 
that Poland's western border should run along the Oder and the coastline of the Baltic Sea. ${ }^{42}$

In his conversation with British Foreign Minister Anthony Eden on 5 October 1943, Polish Prime Minister Stanisław Mikołajczyk confirmed that the Polish side was opposed to the discussing of the future Polish-Soviet border at the planned Moscow Conference. ${ }^{43}$

Also worth mentioning is the formal position of the Polish government in this matter, contained in the memorandum dated 16 November 1943. The document defined the Polish demands before the Tehran Conference:

[...] the Polish eastern lands that are the subject of Soviet claims constitute more than a half of the Polish Republic. Several important centres of Polish national life are located within. They are closely tied with Poland by historical, civilisational and cultural bonds. The ethnic Poles, who have been living there for centuries, constitute the majority of the population of these lands.

The Polish government sees no possibility of discussing territorial concessions especially on the grounds that, in the absence of effective guarantees of Poland's independence and security from Great Britain and the United States, such a discussion would certainly prompt further demands.

The transfer of East Prussia, Gdańsk and Opole Silesia (Upper Silesia) to Poland, and thereby the straightening and shortening of the Polish western border is in any case dictated by the necessity to ensure the durability of future peace, the disarmament of Germany, and the security of Poland and other Central European countries. Granting Poland these territories cannot, therefore, be honestly considered a compensation for the loss of its eastern lands, which, for the reasons defined above, do not represent the same value for the USSR as they do for Poland. ${ }^{44}$

Identical demands concerning the annexation of the above-mentioned lands were included in another document of the Polish authorities, dated 7 December 1943 (Theses adopted by the Council of Ministers with regard to the incorporation and occupation of the eastern territories of Germany). ${ }^{45}$

The pivotal moment in this matter was the discussion between the leaders of the three Great Powers (Franklin D. Roosevelt, Winston Churchill and Joseph Stalin) at the Tehran Conference, which took place from 28 November to 1 December 1943. Eventually, it was decided - without consulting the Polish authorities - that "the core of the Polish nation and state should be located between the Curzon Line and the Oder River, with the inclusion of East Prussia and the Opole province". It should be emphasised that Stalin also insisted that the two Baltic ports of Königsberg and Memel (Klaipeda), as well as the

\footnotetext{
${ }^{42}$ Orzechowski, Odra - Nysa Łużycka - Bałtyk, pp. 116-118, 140-141.

${ }^{43}$ Historia Dyplomacji Polskiej, vol. 5, p. 422.

44 Sprawa polska, pp. 418-419.

${ }^{45}$ Ibid., pp. 431-433.
} 
corresponding territories of East Prussia, be placed within the borders of the Soviet Union. ${ }^{46}$

The crossing of the pre-war Polish-Soviet border by the Red Army on 3-4 January 1944 prompted the Polish authorities to issue a statement two days later, on 5 January 1944. The Polish Government-in-Exile asserted that Poland would refuse to recognise any decisions imposed by force. He expected the Soviet Union to respect the rights of the Polish Republic and its citizens. The statement reminded that the Polish authorities had issued an instruction to the Home Army on 27 October 1943, in which they ordered the Polish Underground forces to avoid any armed conflict with the Red Army in the event of its entry into Polish territory. The Home Army was obliged to cooperate with the Soviet command as soon as the governments of the two states would resume diplomatic relations. ${ }^{47}$

The official position of the Soviet authorities in respect of the Poland's postwar borders was summarised in the TASS communiqué dated 11 January 1944, formulated as a response to the statement of the Polish government of January 5. The document asserted that the Soviet Constitution had established the border between the USSR and the Polish Republic in consonance with the results of the plebiscites organised in Western Ukraine and Western Belarus in 1939. The two territories were consequently incorporated, in accordance with the will of their inhabitants, into Soviet Ukraine and Soviet Belarus.

The statement suggested that the Soviet-Polish border should be founded on the Curzon Line, adopted in 1919 by the Supreme Council of the Allied and Associated Powers as a future demarcation line between Poland and Russia. The line was equivalent to the incorporation of Western Ukraine and Western Belarus into the Soviet Union. The western borders of Poland were to move further west by virtue of the inclusion of historically Polish territories formerly occupied by Germany. This would allegedly constitute a solution for the unification of the entire Polish nation within its own state, which would thereby obtain wide access to the Baltic Sea. ${ }^{48}$

This rationale was founded on a unilateral and biased assumption that Western Ukraine and Western Belarus were inhabited only by Ukrainians and Belarusians, with no regard to the presence of Polish and Jewish communities.

The Treaty of Riga had not been imposed to the Soviet side, but instead was the result of Polish-Soviet negotiations. But of course, the suggestion contained in the communiqué, which affirmed that Germany's concessions should include

${ }^{46}$ Ibid., p. 429. For more on this subject, see: J. Tebinka, Polityka brytyjska wobec problemu granicy polsko-radzieckiej 1939-1945, Warszawa, 1998, pp. 291-302. The Tehran Conference is mentioned by Kersten, Warianty polityki polskiej, pp. 34-35.

47 Dokumenty i materiały do historii stosunków polsko-sowieckich, vol. 8, Warszawa, 1974, pp. 6-7; W. Pobóg-Malinowski, Najnowsza historia polityczna Polski 1864-1945, vol. 3, London, 1960, p. 496.

48 Sprawa polska, pp. 455-456. 
the territories that had been part of the Polish state in the time of the first Piasts, was reasonable.

The conclusions of the Tehran Conference, as well as the TASS communique of 11 January 1944 (widely quoted in the present study), both had a significant impact on the contents of the broadcasts of the Tadeusz Kościuszko Radio Station concerning the issue of Poland's post-war borders.

It is worth pointing out that the document of 11 January 1944 was the subject of the broadcast of January 12 . In early 1944, the radio station reported on the diplomatic polemics between the Soviet and Polish governments, in which the issue of Poland's post-war borders featured prominently.

The subject was addressed again only in the spring of 1944, as evidenced by the radio broadcast of April 14. It contained the idea of expelling the German population living in Silesia and Pomerania, deemed unwelcome in these areas after the end of the war. "The incorporation of - historically Polish - northern and western territories that the Germans have forcefully torn away from their Motherland will greatly expand our resources and facilitate the abolition of poverty in the Polish countryside. The Germanhood will be forced out not only from Greater Poland, but from all over Upper Silesia, Pomerania, Gdańsk and East Prussia, and this land will be taken over by the Polish peasants". ${ }^{9}$

Poland's access to the sea was expected to contribute to the economic development of the country, and to increase protection against possible attacks from Germany. This stance was repeatedly declared in the broadcasts. Throughout its period of activity, the radio station promoted the concept of reclaiming the so-called limites of the Piasts. The broadcast of 22 June 1944 asked:

What does the sea mean to the state? It is a safe, natural boundary, a free and practical gateway into the world; it is a great reservoir of energy, as well as mineral, animal and vegetal resources. Therefore, the sea bears vital strategic, political, cultural and economic importance. [...] What does the Baltic Sea mean to us, Poles? It protects our northern border, and delimits our possessions, our national territory from the north. It means shattering the northern arm of the spanner, which the insidious Prussian tyrants had been tightening on our Motherland since the $18^{\text {th }}$ century. Cutting the Pomeranian and East Prussian tentacles off the Prussian core, freeing the Slavic lands, Polish Pomerania, Polish and Lithuanian East Prussia from the axe of the German coloniser, the violence of the Junker, the exploitation by the German landowner, is a prerequisite for guaranteeing Poland's security against renewed attempts of German aggression..$^{50}$

The theses contained in the above-quoted broadcast can be considered legitimate, as the shape of Poland's pre-war borders indeed contributed to the difficulties that the Polish Armed Forces encountered in their attempts to repel the troops of

\footnotetext{
49 Broadcast of 14 April 1944, AAN, Radiostacja, vol. 25, fol. 188.

50 Broadcast of 22 June 1944, ibid., vol. 27, fol. 351.
} 
the Third Reich and the USSR. It should also be mentioned that the radio broadcasts resorted to historical arguments to make the audience aware of how these unfavourable borders with Germany had threatened Polish statehood in the past.

The broadcasts were intended to draw the attention of their audience to the fact that "without unrestricted, widespread access to the Baltic, Poland would at most be an imitation of a strong, independent state". ${ }^{51}$

The authors of the broadcasts frequently employed various arguments - often having recourse to historical events - to prove that Pomerania was a culturally and politically Slavic, thus Polish region. At the same time, they pointed out that these lands had been invaded by the Germans, and, therefore, there were no grounds for them to remain on the German side of the border after the war.

Are we entitled to Pomerania? Are we entitled to the Polish lands in East Prussia? Beyond any doubt, we are. Both historically, and ethnically. The lands from the Vistula to the Oder, from the Oder to the Persante [Parsęta], ${ }^{52}$ and further west between the Warta line and the Baltic Sea, all were uniformly Slavic in the $6^{\text {th }}, 7^{\text {th }}$ and $8^{\text {th }}$ centuries. Populous, sedentary tribes of rich and cultural Pomeranian Slavs lived there; they were as brethren to our ancestors. In the $8^{\text {th }}$ century, the cruel German colonization began to drive them out, assault them, and eradicate them. With fire and sword, they have been banished from their fatherland, chased across the Persante, and decimated. All that is left of them is the name of Pomerania, and the local population: Germanized on the outside, yet Slavic at heart. Eastern Pomerania, from the Persante to the Vistula, has been under Polish sovereignty since the $11^{\text {th }}$ century. Seized through deceit by the Teutonic Knights in the $14^{\text {th }}$ century, the region returned voluntarily under Jagiellonian command in $1466 .{ }^{53}$

The information contained in the cited fragment of the broadcast is rather consistent with historical truth, although it involves many inaccuracies. The Slavs waged wars against the Franks in the $8^{\text {th }}$ century around the Elbe and Saale. Gdańsk Pomerania was conquered in 1308, then returned to Poland in 1466 in consequence of the Second Peace of Thorn.

Access to the Baltic Sea was a necessity for post-war Poland in view of its proper economic and political development. The inclusion of East Prussia into the Polish state was just as crucial, since this region posed an important threat to the security of the country. On 3 May 1944, the broadcast stated: "East Prussia cannot remain in the hands of Germany. Otherwise, it might be used again as a bridgehead, a gateway for aggression against Poland and Lithuania. The Polish territories of East Prussia must return to Poland, and the Lithuanian ones to Lithuania. East Prussia should become Poland's bridge to the sea". ${ }^{4}$

${ }^{51}$ Ibid., fol. 352.

52 Persante (Polish: Parseta), a river in Pomerania, tributary of the Baltic Sea, passes through the towns of Parsęcko, Białogard, Karlino, Wrzosowo, Zieleniowo, Kołobrzeg.

53 Broadcast of 23 June 1944, AAN, Radiostacja, vol. 27, fol. 370.

${ }^{54}$ Broadcast of 03 May 1944, ibid., vol. 26, fol. 38. 
The cited excerpts from the broadcasts were meant to exert influence on the listeners, and prove that an unfavourable settlement of this issue would result in continued attacks on the part of Germany, meaning that Poland would find itself trapped in a state of constant danger. The country would not prosper economically and demographically, marred by recurring war trauma.

The very same rationale was employed in the justification of the inclusion of Silesia. The broadcast also employed economic arguments (rich deposits of fuels and other materials). Of major importance were also the ethnographic factor, the presence of Polish culture in the area, and historical aspects, i.e. the fact that the region had belonged to Poland in the past.

In the south, a narrow German wedge is lodged between Poland and Czechoslovakia. That wedge is called Silesia. A rich land; fertile, abundant in coal, iron ore and zinc ore. A Polish land. A possession of the Piast dynasty. Silesia belonged to Poland for centuries; at the time of Mieszko I, of Boleslaus I the Brave, of Boleslaus III Wrymouth, of Ladislaus I the Elbow-high. Even today, Poles are a majority in a large portion of Silesia [...]. Polish is the people, Polish is the peasant and the worker. Silesia in German hands means the exploitation and oppression of the Polish Silesian people. It means a constant military threat to Cracow and Dąbrowa, to Poznań and Częstochowa. It means the forced separation of two fraternal, Slavic states: Poland and Czechoslovakia. It means harm to Poland, to the entire Polish nation, to all the Slavs. Silesia - as a land of the Piasts, historically Polish territory - must return to its Motherland. ${ }^{55}$

The incorporation of Silesia, East Prussia and West Pomerania by Poland meant that the German community would be unable to live and operate in these areas after the war. One excerpt of the broadcast of 10 March 1944 can be interpreted as a prediction of the future resettlement of the German population. ${ }^{56}$ The idea was justified by reasons of internal security of post-war Poland: "The expulsion of ethnic Germans from Silesia, West Pomerania and East Prussia, is a fundamental prerequisite for the security of the future Polish state. No treaties or guarantees will protect us from assault from the west". ${ }^{57}$

This argument also appeared in another excerpt, on 31 March 1944. The broadcast was about East Prussia, another area that was expected to re-join post-war Poland:

The expulsion of Germanhood from East Prussia means the eradication of East Prussian large holders, of the Junkers embodying the most chauvinist and greedy aspects of the Prussian reaction that has always been the evil spirit of the German people, the source

55 Ibid., fol. 38-39.

56 At the conference of the Big Three in Tehran, its participants decided that the demarcation of Poland's new borders would entail the resettlement of the local populations; see: Tebinka, Polityka brytyjska, p. 299; Historia dyplomacji polskiej, vol. 5, p. 448.

57 Broadcast of 10 March 1944, AAN, Radiostacja, vol. 24, fol. 145. 
of their revanchism, their conquests and their surges toward the east. Breaking once and for all the economic power of the Prussian Junkers, tearing away the poisoned sting of the Prussian viper [sic] will come as a blessing not just for us, but for all the peoples of Europe. ${ }^{58}$

The broadcast suggested that Poland's borders at the time of the early Piasts were optimal, as they protected the country from German assaults and guaranteed economic development. The broadcasts also exposed the political errors committed by former Polish rulers. For instance, they condemned Casimir III the Great for relinquishing Silesia in favour of the Emperor. They also denounced permitting the Hohenzollern dynasty to rule in Ducal Prussia; Sigismund I the Old, and his son Sigismund II Augustus were both blamed for this error, as their political decisions proved to be fatal: Ducal Prussia's ties with the Polish state were severed, leading to the creation of a future threat to Polish statehood (Prussia).

The broadcast of 4 April 1944 depicted the involvement of the Polish element in the east in a negative light. Its presence led to the emergence of a new social layer - the magnates - who contributed greatly to the collapse of the Polish state in the $18^{\text {th }}$ century. ${ }^{59}$ The provided reasoning was aimed at making the audience aware that the outcome of the war could be favourable for Poland in the context of its future borders. On 4 April 1944, the broadcast asserted as follows:

[...] the current war presents us again with the problem of Poland's borders. Historical experience and political common sense tell us that, for the first time in centuries, the situation favours our reclamations in the west. Hundreds of years have passed since we last encountered such an opportunity, and no one knows whether this will happen to us ever again. [...] Prussia, the Vistula and Gdansk, Pomerania, the Oder line, Silesia: the vigilant border guards must stand there to protect the newly-liberated Polish nation. We shall build border mounds and fires as a sign that we have embraced our history, and accepted the testament of the Piasts: self-defence forces, vigilance and iron posts from the west, so that our tormented people could begin a new happy life in a friendly neighbourhood of new Slavic powers. ${ }^{60}$

The radio broadcasts implied that Poland's return in the Recovered Lands was guaranteed by the Soviet Union. This was allegedly evidenced by the presence of the Red Army in the Eastern Borderlands, which had been incorporated into the Soviet state under the laws of the Supreme Soviet of the USSR in the autumn of 1939 in contravention of international law. It should be noted at this point that the issue was discussed by British Ambassador to Moscow Stafford Cripps in his memorandum dated 22 October 1940, wherein he stated that the United Kingdom recognised de facto the Soviet Union's sovereignty over "those parts of the former

\footnotetext{
58 The broadcast of 31 March 1944, ibid., fol. 472.

59 Broadcast of 04 April 1944, ibid., vol. 25, fol. 51-52.

60 Ibid.
} 
Polish state, which are now under Soviet rule" ${ }^{61}$ The formal position of the British Government was contradictory to the provisions of the secret protocol of the British-Polish Agreement of 25 August 1939 - with its third point in particular, which prohibited the conclusion of agreements that violated the territorial integrity of one of the signatories.

The proposals regarding Poland's post-war border presented in Tehran, and the communiqué of the TASS agency of 11 January 1944, indicated that it was the Soviet Union which actually guaranteed protection against a possible attack by Germany. This stance was asserted in the broadcast of February 20: "It goes without saying that our only hope to reclaim our ancient lands in the west and in the Baltic Sea from the Germans, and re-attach them to Poland, is the approval and support bestowed upon us by our mighty Slavic ally, the Soviet Union". ${ }^{62}$ The broadcast of March 31 had a similar overtone: "The experience of the current war proved beyond any doubt that cordial friendship with our eastern neighbour, the largest Slavic state and the greatest power of Europe - the Soviet Union - will constitute a fundamental prerequisite to guaranteeing Poland's future security, and taming once and for all the rapacious endeavours of the Germans". ${ }^{63}$

The above-quoted excerpts seem to prove that the radio station appreciated the importance of Poland's eastern neighbour in the ongoing conflict. It was expected that this country would play a significant role in the international scene, and its status was clearly defined. There was no doubt that the USSR would retain its current position after the end of the Second World War. The Polish crew outlined the future relations between the Soviet Union and Poland, and used its communiqués to promote servility. Poland should be dependent on Moscow, especially in terms of defence.

The radio station also assessed the Polish-Soviet borders from the interwar period. The broadcasters concluded that keeping the Eastern Borderlands would not provide Poland with economic development, as it was an agricultural area with a backward agrarian economy. The broadcast of 10 March 1944 expressed a marked aversion to landed gentry, which benefited materially from the Polish presence in the eastern voivodeships. "Should the economically backward Eastern Lands be incorporated into Poland in their pre-war form, they will soon prove to be rather a burden than a benefit. They may have benefited the Radziwiłl and Lubomirski families, but they did not contribute to strengthening Poland's economic potential". ${ }^{4}$ The language used in the broadcasts clearly aimed at disparaging the Polish aristocracy, unequivocally regarded as responsible for the backwardness

${ }^{61}$ Tebinka, Polityka brytyjska, p. 116. For more on Cripps's memorandum, see: M. Hułas, "Memorandum Stafforda Crippsa z 22 października 1940 r. Polskie aspekty”, Dzieje Najnowsze, 4 (1993), pp. 81-93.

62 Broadcast of 20 February 1944, AAN, Radiostacja, vol. 23, fol. 256.

${ }^{63}$ Broadcast of 31 March 1944, ibid., vol. 24, fol. 471.

${ }^{64}$ Broadcast of 10 March 1944, ibid., fol. 145-146. 
of the Eastern Borderlands. Other arguments were also used to encourage Poles to relinquish the eastern voivodeships. For example, the broadcasters attempted to prove that these lands were distinctly non-Polish. The broadcast of 20 February 1944 stated: "As we fight for the liberation and unification of our lands, we, the Polish nation, want not one inch of Ukrainian, Belarusian or Lithuanian soil. It is not just a question of elementary justice, as the essential principle of democracy. It is also a matter of political reason" ${ }^{65}$

Statistics were widely used to validate the argument that the Ukrainians and Belarusians formed a majority of the population in the Eastern Borderlands, not to mention the significant percentage of Jews and Lithuanians. One of the broadcasts, for instance, listed the predominant denominations of the eastern voivodeships of the Second Polish Republic. Based on this data, the authors of the broadcast could determine the number of Ukrainians, Belarussians, Jews and Lithuanians living in the eastern voivodeships.

Let us consult the Small Statistical Yearbook of the Central Statistics Office (GUS) for the year 1939 [based on data from the 1931 census]. Even official Polish censuses testify that the territories in question are essentially Ukrainian and Belarusian. Take, for example: Stanisławów Voivodeship: 73\% are Greek Catholics, i.e. Ukrainians, Wolhynia Voivodeship: $70 \%$ are Orthodox, i.e. Ukrainians, Polesie Voivodeship: 77\% are Orthodox, i.e. Belarusians. Besides, these voivodeships were also home to a large Jewish minority, up to $10 \%$ of the overall population. Roman Catholics, i.e. Poles, represented less than $20 \%$ of the local population. ${ }^{66}$

The information provided in the broadcast was rather accurate. According to data from the census carried out in 1931, the Stanisławów (now: Ivano-Frankivsk in Ukraine) Voivodeship had a population of: 1,018,436 Ukrainians (68.8\%), 331,583 Poles (22.4\%), 109,541 Jews (7.4\%), ${ }^{67}$ and 16,737 Germans (1.13\%). ${ }^{68}$ In the Wolhynia Voivodeship, there were 1,418,190 Ukrainians (68\%), compared to only 346,205 Poles (16.6\%), 206,471 Jews (9.9\%), and 114,706 representatives of other nationalities (5.5\%). In the Polesie Voivodeship, Belarusians were the dominant majority. There were 782,100 of them $(69.1 \%)$, compared to 164,116 Poles (14.5\%), 113,183 Jews (10\%), and only 54,328 Ukrainians (4.8\%). ${ }^{69}$

65 Broadcast of 20 February 1944, ibid., vol. 23, fol. 256.

${ }^{66}$ Broadcast of 14 April 1944, ibid., vol. 25, fol. 194.

${ }^{67}$ P. Eberhardt, Polska granica wschodnia 1939-1945, Warszawa, 1993, p. 43; see also: Maly Rocznik Statystyczny, Warszawa, 1939, pp. 22-25. The results of the 1931 census concerning the ethnic composition of the Stanisławów Voivodeship are presented in: G. Hryciuk, Przemiany narodowościowe i ludnościowe w Galicji Wschodniej i na Wołyniu w latach 1931-1948, Toruń, 2005, p. 78; G. Hryciuk, J. Stoćkyj, Studia nad demografia historyczna i sytuacja religijna Ukrainy, Lublin, 2000, pp. 70-72.

${ }^{68}$ Hryciuk, Przemiany, p. 78.

${ }^{69}$ Eberhardt, Polska granica wschodnia, pp. 38, 37. 
The above-quoted data proves that Poles constituted a minority compared to Ukrainians and Belarusians. As a consequence, the eastern voivodeships of the Second Polish Republic (Stanisławów, Wołyń, Polesie) should not be included within Poland's post-war borders. However, it should be noted that the results from other voivodeships located in the Eastern Borderlands were deliberately omitted, as they proved that the Polish community predominated or constituted only slightly less than a half of the population in these areas. These figures also come from the 1931 census. In the Wilno (Vilnius) Voivodeship, ${ }^{70}$ the Poles constituted a majority, at 761,735 inhabitants (59.7\%). The second largest community was Belarusians, at 289,638 (22.7\%), followed by Jews at 109,730 (8.6\%), Lithuanians at 66,348 (5.2\%), and representatives of other nationalities at 48,485 (3.8\%); Nowogródek Voivodeship: 553,945 Poles (52.4\%), 413,344 Belarusians (39.1\%), 77,171 Jews (7.3\%), and 12,685 representatives of other nationalities (1.2\%); Tarnopol Voivodeship: 789,000 Poles (49.3\%), 728,184 Ukrainians (45.5\%), 78,419 Jews $(4.9 \%),{ }^{71}$ and 2,675 Germans $(0.16 \%) .{ }^{72}$ The eastern part of Lwów (Lviv) Voivodeship: 737,835 Poles (44.75\%), 747,808 Ukrainians (45.35\%), 148,972 Jews (9.04\%), and 11,199 Germans $(0.68 \%){ }^{73}$

The results of the 1931 census raise objections, considering the cases of intimidation of the Polish population in the towns where the Ukrainians predominated. Such incidents are known to have occurred in the Stanisławów and Tarnopol Voivodeships. There were also cases of distortions on the part of the census commissioners who would classify the local population as they saw fit, depending on their own ethnicity.

The above-quoted data confirms Polish presence in the Eastern Borderlands, thus validating the return of these voivodeships to Poland after the war; a fact worth emphasising, since it was refuted in the broadcasts of the Tadeusz Kościuszko Radio Station.

However, the ethnic composition changed during the Second World War. On 1 March 1943, the authorities of the General Government conducted a general census, which covered the areas of the former Lwów, Tarnopol, and Stanisławów

${ }^{70}$ For information on the circumstances of the transfer of Wilno Land to Lithuania by the USSR (autumn 1939) and its ethnic composition, see: P. Łossowski, Litwa a sprawy polskie 1939-1940, Warszawa, 1985, p. 56. The period of the German occupation of the Wilno Land, especially with regard to administrative and national issues, is described by A. Srebrakowski: "Zmiany składu narodowościowego w części Wileńszczyzny wcielonej do Litwy w okresie II wojny światowej”, in: Przemiany narodowościowe na Kresach Wschodnich II Rzeczypospolitej 1931-1948, ed. S. Ciesielski, Toruń, 2004, pp. 324, 325, 329, 337, 338, 339, 341.

71 Eberhardt, Polska granica wschodnia, p. 35, 36, 42; Maly Rocznik, pp. 22-25; The results of the 1931 census concerning the ethnic composition of the Tarnopol Voivodeship are presented in: Hryciuk, Przemiany, p. 79; Hryciuk, Stoćkyj, Studia, pp. 73-75.

72 Hryciuk, Przemiany, p. 79.

${ }^{73}$ The results of the 1931 census concerning the ethnic composition of the eastern part of the Lwów Voivodeship are presented in: Hryciuk, Przemiany, p. 80; cf. Hryciuk, Przemiany, p. 79; Hryciuk, Stoćkyj, Studia, pp. 67-69. 
Voivodeships. The Lwów Voivodeship was inhabited then by: 375,108 Poles (25.9\%), 988,407 Ukrainians (68.25\%), 32,258 Germans (2.23\%), 40,957 Jews (2.83\%), and 8,906 representatives of other nationalities $(0.61 \%)$. The Tarnopol Voivodeship had a population of: 286,429 Poles (19.09\%), 1,156,782 Ukrainians (77.08\%), 13,317 Germans (0.95\%), 42,473 Jews (2.83\%), and 771 representatives of other nationalities $(0.05 \%)$. In the Stanisławów Voivodeship, there were: 137,891 Poles (10.74\%), $1,117,651$ Ukrainians (87.04\%), 21,728 Germans (1.69\%), and 4,036 Jews (0.39\%). ${ }^{74}$

When comparing the results of the Polish census conducted in the Stanisławów Voivodeship in 1931 with the German census of 1943, an increase in Ukrainian and German population can be noticed - by 99,215 (9.74\%) and 4,991 (29.82\%) respectively - while the number of Poles and Jews has drastically dropped by 193,692 (58.42\%) and 105,505 (96.32\%). This trend also occurred in the former Tarnopol Voivodeship, where the number of Ukrainians and Germans increased by 428,598 (58.85\%) and 10,642 (397.83\%) respectively, while the Polish and Jewish communities shrunk by 502,571 (63.70\%) and 35,946 (45.84\%). In like manner, the number of Ukrainians and Germans within the borders of the former Lwów Voivodeship had increased by 240,599 (32.17\%) and 21,059 (188.04\%) respectively. The Poles, on the other hand, were largely affected by the war, as their population decreased there by 362,727 (49.17\%); and so had the Jews, of whom there were now fewer by 108,015 (72.51\%).

The occupier has wiped out almost completely the Jewry of the Eastern Borderlands, and reduced significantly its Polish population. It must also be remembered that the local population suffered deportations carried out by the Soviets in 1940 and 1941; and, as a result of the actions of the Nazis, this area was inhabited mainly by Ukrainians.

Defining the ethnic composition of the population of Volhynia (Wołyń) and the losses suffered by individual communities in 1941-1944 is a difficult task. The occupation authorities themselves often used very general data. At a conference in Brest on 27-29 March 1942, the Germans stated that the population of the General Commissariat for Volhynia and Podolia amounted, in the spring of 1942, to 4.6 million, including 3.5 million Ukrainians (76.08\%), 460 thousand Poles (10\%), 280 thousand Belarusians (6.08\%), 33 thousand Russians (0.71\%), 3 thousand Germans $(0.06 \%)$ and 330 thousand Jews $(7.17 \%)$.

According to the census, the territory of the former Wołyn Voivodeship was inhabited in 1942 by 305,741 Poles, representing $14.6 \%$ of the overall population. Therefore, the overall population of the area in 1942 was 2.094 million. ${ }^{75}$ There is no data regarding other nationalities.

${ }^{74}$ Hryciuk, Przemiany, pp. 224-226; cf.: id., "Zmiany ludnościowe i narodowościowe w Galicji Wschodniej i na Wołyniu w latach 1939-1948”, in: Przemiany, pp. 185, 186, 187; Hryciuk, Stoćkyj, Studia, pp. 89-91, 94-99.

${ }^{75}$ Hryciuk, Zmiany ludnościowe, pp. 211, 218. According to the author, the findings so far prove that the irrecoverable losses of the Polish population in Volhynia in 1941-1944 could amount 
There are no known figures either from the former Nowogródek and Polesie Voivodeships. The only information pertains to the Lida area (county of the Nowogródek Voivodeship). During the occupation, it was part of the General Commissariat for Belarus. The district had a population of 267,613, with 192,474 Poles (71.92\%), 66,657 Belarusians (24.9\%), 4,419 Jews (1.65\%), 2,963 Lithuanians (1.10\%), 531 Tatars (0.19\%), 225 Ukrainians (0.08\%), and 76 Germans $(0.02 \%)$.

The ethnic structure of the Brest district (part of the General Commissariat for Volhynia and Podolia), at the turn of 1941 and 1942 is also known. The area, which before the outbreak of the Second World War was part of the Polesie Voivodeship, now had a population of 175,495 . The largest ethnic group were the Ukrainians - 87,766 (50\%) - followed by: 30,502 Poles (17\%), 21,939 Belarusians (12.5\%), 23,564 Jews (13.42\%), 8,085 Russians (4.6\%), 318 Germans (0.18\%), and 3,147 representatives of other nationalities $(1.79 \%) .{ }^{76}$

The above statistics prove that the Polish population was a minority in the areas subject to the General Commissariat for Volhynia and Podolia. The Ukrainian population predominated there. Poles formed a definitely larger community in the Lida district, which was part of General Commissariat for Belarus. Unfortunately, only fragmentary data is available, as no exact census had been conducted in this territory. It undoubtedly makes it difficult to ascertain the extent to which the national policy pursued by the USSR (in the years 1939-41) and the Third Reich (since 1941) has changed the ethnic mosaic in the areas mentioned above. There is no doubt that the actions undertaken by both totalitarian states with regard to the Poles caused their number to decline in this area. However, neither the Soviets nor the Nazis succeeded in wiping out the Polish element.

The Tadeusz Kościuszko Radio Station also informed about the number of Poles in two cities of the Eastern Borderlands: Wilno and Lwów. Allegedly, Poles were not a majority in either. The broadcast of 14 April 1944 stated: "Even in pre-war Lwów and Wilno, Poles alone (i.e. without the Jews) did not constitute a majority of the population". ${ }^{77}$ This had little to do with the truth. In 1931, Wilno had a population of 195,071, out of which 128,551 (65.9\%) were Poles. Other communities included: Jews: 54,619 (28\%), Belarusians: 1,755 (0.9\%), Lithuanians: 1,560 (0.8\%), and other nationalities: $8,583(4.4 \%) .^{78}$ As regards Lwów, it had

to 70 thousand, of which 36.7 to 60 thousand would be the Polish victims of the Ukrainian "ethnic cleansing" carried out in 1943. For more, see: Hryciuk, Przemiany, p. 279.

${ }^{76}$ M. Ruchniewicz, "Stosunki narodowościowe w latach 1939-1948 na obszarze tzw. Zachodniej Białorusi”, in: Przemiany, pp. 279-280.

77 Broadcast of 14 April 1944, AAN, Radiostacja, vol. 25, fol. 195.

${ }^{78}$ Eberhardt, Polska granica wschodnia, pp. 35. According to the census conducted in Lithuania on 27 May 1942 by the Lithuanian authorities, Wilno had a population of 143,498 , including 103,203 Poles (71.92\%), 29,480 Lithuanians (20.54\%), 6,012 Russians (4.19\%), 3,029 Belarusians (2.11\%), 476 Germans (0.33\%), 78 Latvians (0.05\%), 697 representatives of other nationalities $(0.49 \%)$, and 523 people with no nationality stated $(0.37 \%)$. More on this subject: A. Srebrakowski, "Zmiany składu narodowościowego w części Wileńszczyzny wcielonej do Litwy w okresie II wojny 
312,231 inhabitants in 1931. The Polish population constituted a majority there too, at 198,266 people (63.5\%); and Jews formed the largest minority, at 75,247 (24.1\%). Statistical data hardly proves the Ukrainianness of this city, as there were only 34,969 Ukrainians $(11.2 \%)$ there at that time. Other nationalities amounted to $3,746(1.2 \%){ }^{79}$

In 1943, Lwów had a population of 254,291 . The Poles still formed a majority with 139,014 residents (54.67\%), although the Ukrainian population had increased over time, reaching $68,377(26,89 \%)$. The German community had also increased to $18,407(7.24 \%)$, while the number of Jews dropped to $20,078(7.9 \%) .{ }^{80}$

Based on the available data, it can be stated that, before the outbreak of the Second World War, both urban centres (Wilno and Lwów) were predominantly Polish. The Lithuanians in Wilno and the Ukrainians in Lwów constituted small minorities, even less numerous than the Jews. Taking into account the ethnic criterion, there were no grounds for these cities to be separated from the Polish state.

The broadcasts of the Tadeusz Kościuszko Radio Station were meant to play on the emotions of the Polish audience; for instance, the radio broadcast of 21 January 1944, featured an account by a former Polish settler from Volhynia. The landowner portrayed the threats Poles would endure on the part of Ukrainians living in the eastern voivodeships, who were hostile toward Polish presence in Western Ukraine. As is well known, many conflicts arose between Poles and Ukrainians during the interwar period, and further escalation occurred during the Second World War, as evidenced by the events in Volhynia in 1943, when thousands of Poles were murdered by Ukrainian nationalists.

A few years after the [Polish-Bolshevik] war, I have been granted a large landholding in Wołyń, and stayed there as an osadnik until 1937. I am therefore aware of the situation

światowej”, in: Przemiany, pp. 342, 349. R. Korab-Żebryk provides erroneous information on the census conducted in Wilno in 1942 by the Lithuanian authorities and its commissars. The author states that Wilno had a population of 97 thousand Poles (57\%), 33 thousand Lithuanians (19.41\%), 3 thousand Germans (1.76\%), and 37 thousand Russians and Belarussians (21.76\%). In total, Wilno would have had 170 thousand inhabitants. It should be mentioned that R. Korab-Żebryk did not use archival sources in his work, but rather the underground periodical Niepodległość, no. 7-8 (30 April 1943). For more on this subject, see: R. Korab-Żebryk, Operacja wileńska AK, Warszawa, 1985. Korab-Żebryk's data on the ethnic structure of Wilno is then reiterated by: S. Lewandowska, Życie codzienne Wilna w latach II wojny światowej, Warszawa, 1997, p. 305; ead., Losy wilnian: zapis rzeczywistości okupacyjnej: ludzie, fakty, wydarzenia 19391945, Warszawa, 2004, p. 321. The same author uses data gathered by the NKVD to state that, in late 1944, Wilno was inhabited by 84,990 Poles (79.8\%), and Lithuanians 7,958 (7.47\%), with an overall population of 106,500; see: S. Lewandowska, Wilno 1944-1945: oczekiwania i nastroje, Warszawa, 2007, p. 65.

79 Eberhardt, Polska granica wschodnia, p. 40.

${ }^{80}$ Hryciuk, Przemiany, p. 224. Other sources state that in 1943, Lwów counted 246,553 inhabitants: 139,014 Poles (56.38\%), 68,377 Ukrainians (27.73\%), 13,382 Germans (5.25\%), and 20,119 Jews (7.89\%); see: Hryciuk, Stoćkyj, Studia, pp. 89, 94, 97. 
there. I have to admit that this policy of settlement in Ukrainian territories was entirely a mistake, which brought us more troubles than benefits. The local Ukrainian population regarded us with hostility. To tell the truth, I felt there as if I were living in a besieged fort. A rifle hung on the wall. I never left home unarmed. Material troubles were significant. Until the very end I have not been able to pay off my debts. We could not count, of course, on support from the Ukrainian population, who perceived us as intruders. In 1936, my homestead was burnt down. Then again in 1937. Eventually, I came to the conclusion that I should forget altogether about getting rich in the Borderlands. ${ }^{81}$

In conclusion, the position of the political superiors of the Tadeusz Kościuszko Radio Station on Poland's future borders was that the eastern voivodeships of the Polish Republic should be transferred to the Ukrainian, Belarusian and Lithuanian Soviet Republics. Key cultural, scientific and economic centres would be taken over by the Soviet state. The proposed shape of the Polish-Soviet border, based on ethnic criteria, thus following the Curzon Line, was at variance with the Polish raison d'état. The territorial acquisitions in the west were to serve as compensation for the possessions lost in the east. This approach was explained with matters of national security and future economic progress. The reasoning behind the Polish-German demarcation line proposed in the broadcasts was actually reasonable. Access to the Baltic Sea provided an opportunity for economic development and protected the country from further attacks by Germany. The theses concerning Poland's post-war borders were in line with the programme of the Union of Polish Patriots, a Polish socio-cultural organisation operating in the USSR. The concept of the Polish border running along the Oder line, which the Polish communists dubbed "reclaiming the limites of the Piasts", essentially amounted to moving the border as far west as possible in order to expand the sphere of influence of the Soviet Union. The course of the war, and the political decisions made throughout, all pointed to this outcome.

The broadcasts were addressed mainly to uneducated people (peasants, workers), therefore the language used was simple and understandable. They were meant to influence the emotions of the audience, which is why the arguments contained therein were illustrated with historical facts, often recounted in a biased manner, as in the case of Polish-German relations. Obviously, the message of the broadcasts depended on the current state of global politics. The position of the Soviet authorities in respect of Poland's post-war borders obliged the broadcasters to present the issue from the standpoint of the interests of the Soviet state.

${ }^{81}$ Broadcast of 21 January 1944, AAN, Radiostacja, vol. 22, fol. 316. 


\section{Issues of land reform and Poland's post-war borders in the broadcasts of Tadeusz Kościuszko Radio Station Abstract}

According to the Polish-language station operating in the territory of the Soviet Union from August 1941 to August 1942, the land reform should consist in expropriating the owners of large landholdings and distributing their possessions among peasants and farm labourers. First in line were those peasants who fought against the German occupier during the war; second were those farmers, who lost their possessions on account of the occupier's legislation. The reform would also include broad financial assistance from the state. A rural self-government system was also planned in order to guarantee the proper development of the country.

As regards the Poland's future borders, the broadcasters presented the position of its political superiors, according to whom the eastern voivodeships of the Polish Republic should be transferred to the Ukrainian, Belarusian and Lithuanian Soviet Republics. Key cultural, scientific and economic centres would therefore be taken over by the Soviet state. The shape of the border was to follow the Curzon Line, at variance with the Polish raison d'etat. The losses in the east were to be compensated by the recovered lands in the west. This approach was explained with matters of national security and future economic progress.

The Station's position on both the land reform and Poland's future borders reflected the opinions of the Polish communists from the Union of Polish Patriots and the Polish Workers' Party.

The broadcasts were addressed mainly to non-educated people (peasants, workers), and for this reason the language used was simple and plain; they were meant to play on emotions, so they were illustrated by distorted and biased historical facts.

Translated by Jakub Perliński

\section{Вопросы аграрной реформы и послевоенных границ Польши в передачах радиостанции им. Тадеуша Костюшко Аннотация}

Позиция радиостанции им. Т. Костюшко по аграрной реформе была следующей: изменения должны были заключаться в том, что землю, принадлежавшую т. н. крупной собственности надо парцеллировать и передать крестьянам и батракам. Стоит подчеркнуть, что землю обязаны были получить земледельцы, которые вели национально-освободительную деятельность во время Второй мировой войны. Очередное предложение, высказанное в эфире радиостанции, шло в направлении возвращения земледельческих хозяйств тем крестьянам, которые потеряли их в результате окуппационного законодательства. Неотъемлемым элементом аграрной реформы было оказание им, предоставленной государством, широко понимаемой, материальной помощи. Планировалось образовать сельское самоуправление, которое гарантировало бы развитие деревни.

Польскоязычная радиостанция взялась представить в эфире вопрос аграрной реформы, так как этой проблемой занимались польские коммунисты, действовавшие в СПП и ППР. Он был существенен из-за «земельного голода», царствовавшего среди крестянства в период межвоенного двадцатилетия. Несомненно, проявление коммунистами интереса к этому вопросу проистекало из желания привлечь на свою сторону эту часть общества. Польскими левыми создавались тогда разные концепции изменения характера собственности в польской деревне, так как сложно было определить один вариант, который был бы реализован в послевоенных условиях. Оценивая работу 
польской радиостанции, надо констатировать, что вопрос аграрной реформы, несмотря на большое значение, не преобладал в ее сообщениях.

В соответствии с мнением политических руководителей радиостанции им. Тадеуша Костюшко, ее позиция на тему будущих границ Польши, была такова, что восточные воеводства Речи Посполитой должны войти в состав Украинской, Белорусской и Литовской ССР. Советское государство должно было перенять важные для Польши культурные, научные и экономические центры. Продвигаемая линия польско-советской границы, должна была проходить по этническим критериям вдоль линии Керзона, вопреки польским национальным интересам. Компенсацией за потерянное на Востоке имущество должны были стать территориальные приобретения на Западе. Это объяснялось соображениями национальной безопасности и будущего экономического развития. Можно согласиться с аргументами, представленными в передачах, касающимися польско-немецкого размежевания. Доступ к Балтийскому морю был для Польши шансом на экономическое развитие, а также шансом обезопаситься от очередного нападения со стороны Германии. Тезисы, касающиеся границ послевоенной Польши, были тождественны программе Союза Польских Патриотов - польской общественно-культурной организации, действовавшей на территории Советского Союза. Идея польской границы вдоль линии Одры, определяемая польскими коммунистами как “возвращение на пястовские рубежи”, была в принципе концепцией передвижения границы максимально на запад с целью увеличения площади зоны влияния Советского Союза. Военные действия, а также политические решения, которые принимались в их ходе, указывали на такой оборот дел. Передачи были обращены, главным образом, к необразованным людям (крестьянам, рабочим), поэтому язык, который в них употреблялся, был прост и понятен. Они должны были влиять на человеческие эмоции и поэтому содержащиеся в них аргументы иллюстрировались историческими фактами, которые зачастую односторонне представляли нпр. польско-немецкие отношения. Естественно, содержание передач было результатом текущей политики в глобальном масштабе. Позиция властей СССР по вопросу послевоенных границ Польши обязывала работников радиостанции освещать эту проблему согласно интересам Советского государства.

\section{Bibliography}

\section{Sources}

Archives of Modern Records in Warsaw, Radiostacja "Kościuszko", ref. no. 321, vols. 1-28

\section{Literature}

Cieślikowa A., Prasa okupowanego Lwowa, Warszawa, 1997.

Czop E., Obwód lwowski pod okupacją ZSRR w latach 1939-1941, Rzeszów, 2004.

Deklaracja ideowa Związku Patriotów Polskich, ed. E. Syzdek, Lublin, 1983.

Dokumenty i materiaty do historii stosunków polsko-sowieckich, vol. 8, Warszawa, 1974.

Dokumenty programowe polskiego ruchu robotniczego 1878-1984, ed. N. Kołomejczyk, B. Syzdek, Warszawa, 1986.

Eberhardt P., Polska granica wschodnia 1939-1945, Warszawa, 1993.

Gogol B.B, Czerwony Sztandar. Rzecz o sowietyzacji ziem Małopolski Wschodniej, wrzesień 1939-czerwiec 1941, Gdańsk, 2000.

Gontarczyk P., Polska Partia Robotnicza. Droga do władzy (1941-1944), Warszawa, 2006. 
Góra W., PPR w walce o podziat ziemi obszarniczej 1944-1945, Warszawa, 1962.

Historia Dyplomacji Polskiej, vol. 5, ed. W. Michowicz, Warszawa, 1999.

Hryciuk G., Polacy we Lwowie 1939-1944. Życie codzienne, Warszawa, 2000.

Hryciuk G., Przemiany narodowościowe i ludnościowe w Galicji Wschodniej i na Wołyniu w latach 1931-1948, Toruń, 2005.

Hryciuk G., Stoćkyj J., Studia nad demografią historyczną i sytuacja religijną Ukrainy, Lublin, 2000.

Hułas M., "Memorandum Stafforda Crippsa z 22 października 1940 r. Polskie aspekty", Dzieje Najnowsze, 4 (1993).

Kersten K., "Warianty polityki polskiej: rok 1944”, Polska 1944/1945-1989. Studia i materiaty, 1 (1995).

Kołomejczyk N., Paweł Finder, Warszawa, 1977.

Korab-Żebryk R., Operacja wileńska AK, Warszawa, 1985.

Kowalski J., "Rozgłośnia im. Tadeusza Kościuszki (fragment wspomnienia)”, Z Pola Walki, (4) 1961.

Kształtowanie się podstaw programowych Polskiej Partii Robotniczej w latach 1942-1945. Wybór materiałów i dokumentów, Warszawa, 1958.

Lewandowska S., Losy wilnian: zapis rzeczywistości okupacyjnej: ludzie, fakty, wydarzenia 1939-1945, Warszawa, 2004.

Lewandowska S., Wilno 1944-1945: oczekiwania i nastroje, Warszawa, 2007.

Lewandowska S., Życie codzienne Wilna w latach II wojny światowej, Warszawa, 1997.

Łossowski P., Litwa a sprawy polskie 1939-1940, Warszawa, 1985.

Madajczyk Cz., Sprawa reformy rolnej w Polsce 1939-1944. Programy i taktyka, Warszawa, 1961.

Mały Rocznik Statystyczny, Warszawa, 1939.

Nadolski M., Komuniści wobec chłopów w Polsce 1941-1956: mity i rzeczywistość, Warszawa, 1993.

Nadolski M., Kwestia chłopska $w$ polityce stronnictw robotniczych i ludowych $w$ Polsce $w$ latach 1941-1947, Warszawa, 1990.

Nazarewicz R., Komintern a lewica polska. Wybrane problemy, Warszawa, 2008.

Organizacja i działania bojowe Ludowego Wojska Polskiego w latach 1943-1945, vol. 4: Działalność aparatu polityczno-wychowawczego, ed. I. Blum, Warszawa, 1963.

Orzechowski M., Odra - Nysa Łużycka - Bałtyk w polskiej myśli politycznej okresu drugiej wojny światowej, Wrocław-Warszawa-Kraków, 1969.

Pobóg-Malinowski W., Najnowsza historia polityczna Polski (okres 1864-1945), vol. 3, London, 1960.

Polska Partia Robotnicza. Dokumenty programowe 1942-1948, Warszawa, 1984.

Programy polskich partii politycznych i ugrupowań partyjnych lat wojny i okupacji hitlerowskiej, comp. by K. Przybysz, Warszawa, 1987.

Prus E., "Problem ziem zachodnich w działalności Związku Patriotów Polskich w ZSRR", Zaranie Ślaskie, 3 (1974), no. 3.

Przygoński A., Z zagadnień strategii frontu narodowego PPR 1942-1945, Warszawa, 1976.

Ruchniewicz M., "Stosunki narodowościowe w latach 1939-1948 na obszarze tzw. Zachodniej Białorusi", in: Przemiany narodowościowe na Kresach Wschodnich II Rzeczypospolitej 19311948, ed. S. Ciesielski, Toruń, 2004.

Słabek H., O społecznej historii Polski 1945-1989, Warszawa, 2009.

Sobczak K., "Geneza Związku Patriotów Polskich w ZSRR i 1 Dywizji Piechoty im. Tadeusza Kościuszki. Maj 1942-czerwiec 1943 r.”, Wojskowy Przegląd Historyczny, 1 (1963).

Sobczak K., “Z genezy Armii Polskiej w ZSRR”, Wojskowy Przegląd Historyczny, 3 (1973).

Sobór-Świderska A., Jakub Berman. Biografia komunisty, Warszawa, 2009.

Sprawa polska $w$ czasie drugiej wojny światowej na arenie międzynarodowej. Zbiór dokumentów, Warszawa, 1965. 
Srebrakowski A., "Zmiany składu narodowościowego w części Wileńszczyzny wcielonej do Litwy w okresie II wojny światowej", Przemiany narodowościowe na Kresach Wschodnich II Rzeczypospolitej 1931-1948, ed. S. Ciesielski, Toruń, 2004.

Syzdek E., Działalność Wandy Wasilewskiej w latach drugiej wojny światowej, Warszawa, 1981. Szumiło M., "I sekretarze Komitetów Wojewódzkich PPR (1944-1948) - portret zbiorowy", Dzieje Najnowsze, 4 (2013)

Szumiło M., "Kadra kierownicza centralnego aparatu PPR w latach 1944-1948”, Res Historica, 34 (2012).

Szumiło M., "Kierownictwo Polskiej Partii Robotniczej (1944-1948) - portret historyczno-socjologiczny", in: Kwartalnik Historyczny, 2 (2014).

Szumiło M., Roman Zambrowski 1909-1977. Studium z dziejów elity komunistycznej w Polsce, Warszawa, 2014.

Tebinka J., Polityka brytyjska wobec problemu granicy polsko-radzieckiej 1939-1945, Warszawa, 1998.

Zbiniewicz F., Armia Polska w ZSRR. Studia nad problematyka pracy politycznej, Warszawa, 1963.

Zbiniewicz F., "Polska lewica demokratyczna w Związku Radzieckim i jej rola w organizacji ludowych regularnych sił zbrojnych w ZSRR”, in: 20 lat ludowego Wojska Polskiego, Warszawa, 1967.

Адибэков Г., Шахназарова Э., Ширина К.К., Организационная структура Коминтерна 1919-1943, Moscow, 1997.

Лебедева Н.С., “Коминтерн и вторая мировая война (после 22 июня 1941 года)”, in: История коммунистичэского Интернационала 1919-1943. Документальные очэрки, ed. А.О. Чубарьян, Moscow, 2002.

Adrian Karolak, PhD in History, doctoral thesis: Propaganda and information activities of the Tadeusz Kościuszko Radio Station in the years 1941-44 (2013); his research interests lie in Polish-Soviet relations during the Second World War (adriankarolak@onet.eu). 